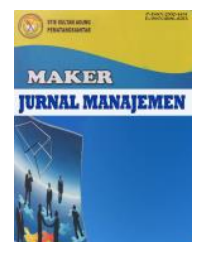

Maker: Jurnal Manajemen

Program Studi Manajemen STIE SULTAN AGUNG

Volume 6- Nomor 1, Juni 2020, (HIm 54-63)

Available online at: http://www.maker.ac.id/index.php/maker

\title{
PENGARUH DESKRIPSI PEKERJAAN DAN KOORDINASI TERHADAP KINERJA PEGAWAI PADA KANTOR PUSAT GEREJA KRISTEN PROTESTAN SIMALUNGUN (GKPS) PEMATANGSIANTAR
}

\author{
Edy Dharma ${ }^{1)}$ *, Fitri Yanti Sinaga ${ }^{2)}$, Lora Ekana Nainggolan ${ }^{3)}$, Sisca ${ }^{4}$ \\ ${ }^{1,2,3,4}$ Program Studi Manajemen, STIE Sultan Agung. Jalan Surabaya No. 19, Kota Pematangsiantar, \\ Sumatera Utara, 21118, Indonesia. \\ *E-mail: 1edydharma@stiesultanagung.co.id, ${ }^{2}$ fitri.yantis@gmail.com, \\ ${ }^{3}$ loraekananainggolan@ stiesultanagung.ac.id, ${ }^{4}$ sisca@ stiesultanagung.ac.id
}

\begin{abstract}
Abstrak
Riset bertujuan mengetahui, yakni: 1. gambaran deskripsi pekerjaan, koordinasi, serta kinerja pegawai pada Kantor Pusat Gereja Kristen Protestan Simalungun (GKPS) Pematangsiantar; 2. pengaruh deskripsi pekerjaan dan koordinasi terhadap kinerja pegawai pada Kantor Pusat Gereja Kristen Protestan Simalungun (GKPS) Pematangsiantar. Untuk memperoleh hasil riset digunakan desain penelitian kepustakaan dan lapangan, sehingga disimpulkan bahwa deskripsi pekerjaan, koordinasi, dan kinerja pegawai telah baik; hasil analisis regresi yakni: $\hat{Y}=13,766+0,546 X_{1}+0$, $518 \mathrm{X}_{2}$ berarti deskripsi pekerjaan dan koordinasi berpengaruh positif terhadap kinerja; hasil analisis korelasi didapat angka $\mathrm{r}=0,743$ maksudnya ada hubungan yang kuat dan positif antara deskripsi pekerjaan dan koordinasi dengan kinerja pegawai pada Kantor Pusat Gereja Kristen Protestan Simalungun (GKPS) Pematangsiantar. Tinggi rendahnya kinerja pegawai 55,1\% bisa dijelaskan oleh deskripsi pekerjaan dan koordinasi; hipotesis $\mathrm{H}_{0}$ ditolak, artinya deskripsi pekerjaan dan koordinasi berpengaruh positif dan signifikan terhadap kinerja pegawai pada Kantor Pusat Gereja Kristen Protestan Simalungun (GKPS) Pematangsiantar baik dengan cara simultan ataupun parsial.
\end{abstract}

Kata kunci: Deskripsi Pekerjaan, Kepuasan Kerja, Kinerja Pegawai

\begin{abstract}
The purpose of this research is: 1. to determine of the job description, coordination, and employee performance at Kantor Pusat Gereja Kristen Protestan Simalungun (GKPS) Pematangsiantar; 2. effect of job description and coordination on employee performance at the Kantor Pusat Gereja Kristen Protestan Simalungun (GKPS) Pematangsiantar. Result of the study can be summerized as follows: job description, coordination, and employee performance are good; the results of the regression analysis are: $\hat{Y}=13,766+0,546 X_{1}+0,518 X_{2}$ means that the job description and coordination have a positive effect on performance; the results of the correlation analysis obtained a value of $r=0.743$ means that there is a strong and positive relationship between job description and coordination with employee performance at Kantor Pusat Gereja Kristen Protestan Simalungun (GKPS). High and low employee performance $55.1 \%$ can be explained by job description and coordination; 4 . the hypothesis $H_{0}$ is rejected, meaning that the job description and coordination have a positive and significant effect on the performance of employees at the Pematangsiantar Simalungun Protestant Christian Church (GKPS) Headquarters both simultaneously and partially.
\end{abstract}

Keywords: Job Description, Job Satisfaction, Employee Performance

Article History: Received 29 April 2020 Accepted 21 May $2020 \quad$ Published 22 June 2020 


\section{PENDAHULUAN}

Kantor Pusat Gereja Kristen Protestan Simalungun (GKPS) Pematangsiantar yang berada di Jalan Pdt. J. Wismar Saragih, Kelurahan Bane, Kecamatan Siantar Utara merupakan organisasi keagamaan di Indonesia yang berlatar belakang kesukuan, yaitu Batak Simalungun, dimana Kantor Pusat Gereja Kristen Protestan Simalungun (GKPS) Pematangsiantar melaksanakan tugas di bidang kerohanian yang sesuai dengan ketentuan peraturan yang ada di Kantor Pusat GKPS Pematangsiantar. Oleh karena itu untuk menunjang aktifitas pelayanan untuk masyarakat maka sangat diperlukannya kinerja yang baik dari para pegawainya.

Mengimbangi kemajuan zaman yang relatif cepat, maka diperlukan tingkat kinerja pegawai yang optimal agar tujuan organisasi tercapai secara efektif dan efisien. Oleh karena itu untuk menunjang kinerja pegawai, organisasi harus memperhatikan salah satu faktor yang mempengaruhinya seperti deskripsi pekerjaan (Syelviani, 2017). Deskripsi pekerjaan adalah sebuah rangkaian daftar tugas, kewajiban, dan tanggung jawab yang diperlukan oleh pekerjaan tertentu. Faktor lain yang mempengaruhi kinerja pegawai Kantor Pusat Gereja Kristen Protestan Simalungun (GKPS) Pematangsiantar adalah koordinasi (Octorano, 2015). Untuk menciptakan koordinasi yang baik bagi pegawai Kantor Pusat Gereja Kristen Protestan Simalungun (GKPS) Pematangsiantar memperhatikan beberapa faktor, yaitu komunikasi, kesadaran pentingnya koordinasi, kompetensi partisipan, kesepakatan, komitmen, dan insentif koordinasi, serta kontinuitas perencanaan.

Berdasarkan latar belakang di atas, penulis ingin mengamati faktor-faktor yang mempengaruhi kinerja pegawai pada Kantor Pusat Gereja Kristen Protestan Simalungun (GKPS) Pematangsiantar terutama untuk melihat sejauhmana adanya kesenjangan antara kenyataan dengan harapan mengenai deskripsi pekerjaan, koordinasi, dan kinerja pegawai pada objek tersebut. Sehingga penulis tertarik untuk melakukan penelitian. Adapun tujuan penelitian ini, yakni untuk mengetahui gambaran dan pengaruh deskripsi pekerjaan dan koordinasi terhadap kinerja pegawai pada Kantor Pusat Gereja Kristen Protestan Simalungun (GKPS) Pematangsiantar.

\section{LANDASAN TEORI}

\section{Deskripsi Pekerjaan}

Menurut Sudaryono (2015:126), deskripsi pekerjaan adalah hal yang menunjukkan informasi tertulis yang menguraikan tugas dan tanggung jawab, kondisi pekerjaan, hubungan pekerjaan, dan aspek-aspek pekerjaan pada suatu jabatan tertentu dalam organisasi. Sedangkan menurut Gaol (2014:152), uraian jabatan adalah suatu pernyataan tertulis yang menerangkan kewajiban-kewajiban, kondisi kerja, dan aspek- aspek lain dari suatu jabatan yang khusus.

Menurut Mathis dan John (2000), deskripsi pekerjaan memiliki manfaat antara lain:

1. Wewenang

a. Wewenang terdefinisikan secara jelas

b. Tidak overlapping dengan posisi lain

c. Kesesuaian wewenang dengan posisi

2. Tanggung Jawab Pegawai

a. Memperoleh kejelasan mengenai tanggung jawab yang diemban secara keseluruhan

b. Arah pertanggungjawaban jelas

c. Kompensasi yang diberikan sesuai dengan tanggung jawab pekerjaan 
3. Kondisi Pekerjaan
a. Peraturan pemerintahan dapat dipahami
b. Kebijaksanaan perusahaan bisa dipahami
c. Adanya kejelasan koordinasi dalam melaksanaan pekerjaan

4. Fasilitas Kerja
a. Kelengkapan fasilitas untuk mendukung kelancaran pekerjaan
b. Kesesuaian fasilitas dengan kebutuhan pekerjaan
c. Kemampuan menggunakan fasilitas kerja

\section{Koordinasi}

Menurut Handoko (2003:193), koordinasi merupakan cara pengintegrasian arah serta kegiatan-kegiatan pada satuansatuan yang terpisah (unit ataupun bidangbidang fungsional) suatu organisasi untuk mencapai tujuan organisasi dengan cara efisien. Selanjutnya menurut Moekizat (2008:1) menjelaskan bahwa koordinasi merupakan sesuatu cara untuk meningkatkan serta menjaga hubungan yang baik di antara kegiatan-kegiatan fisik ataupun kegiatan-kegiatan rohaniah.

Selanjutnya Handayaningrat (2000:129) mengemukakan beberapa masalah dalam mencapai koordinasi yang efektif terdiri dari:

1. Komunikasi

Merupakan penunjukan dan penafsiran suatu pesan di antara unit-unit komunikasi yang merupakan bagian dari suatu organisasi tertentu .

2. Kesadaran pentingnya koordinasi

Dengan memiliki kesadaran akan pentingnya koordinasi akan mempermudah alur pekerjaan dalam organisasi.

3. Kompetensi partisipan pihak yang berwenang atau terlibat dalam mengawasi jalannya koordinasi.

4. Kesepakatan, komitmen dan insentif koordinasi

Merupakan perwujudan dari sebuah kerja sama, tanggungjawab dalam melaksanakan pekerjaan.

5. Kontinuitas perencanaan

perencanaan yang harus dimiliki organisasi untuk mengantisipasi resiko yang akan terjadi.

\section{Kinerja Pegawai}

Menurut Rivai (2015:447), kinerja ialah suatu sebutan secara umum yang dipakai untuk separuh atau semua tindakan maupun kegiatan dari sesuatu organisasi pada suatu periode dengan referensi pada beberapa parameter seperti anggaran masa lalu atau yang diproyeksikan, dengan dasar efisiensi, pertanggungjawaban atau responsibilitas manajemen dan semacamnya.

Selanjutnya menurut Mangkunegara (2017:67), kinerja merupakan hasil kegiatan sebagai kualitas dan kuantitas yang didapat seoarang pegawai dalam melakukan tugasnya sesuai dengan tanggung jawab yang diberikan kepadanya. Sedangkan Menurut Robbins (2006:260), kinerja karyawan memiliki dimensi sebagai berikut:

1. Kuantitas

Kuantitas adalah jumlah yang dinyatakan dalam istilah seperti jumlah unit jumlah siklus aktivitas yang diselesaikan.

2. Kualitas

Kualitas kerja diukur dari persepsi karyawan terhadap kualitas pekerjaanyang dihasilkan serta kesempurnaan tugas terhadap ketrampilan dan kemampuan karyawan.

3. Ketepatan Waktu 
Ketepatan waktu adalah tingkat kegiatan diselesaikan pada awal waktu yang dilihat dari sudut pandang koordinasi dengan hasil keluaran (output) serta memaksimalkan waktu yang ada untuk aktivitas lain.

4. Efektivitas

Evektivitas merupakan tingkat pemanfaatan sumber daya organisasi (tenaga, uang, teknologi, bahan baku) dengan maksud kenaikan hasil dari setiap bagian dalam penggunaan sumber daya.

5. Kemandirian

Kemandirian merupakan tingkat seorang karyawan yang nantinya akan dapat menjalankan fungsi kerjanya tanpa meminta bantuan, bimbingan dari orang lain atau pengawasan.

6. Komitmen Kerja

Komitmen kerja merupakan suatu tingkat dimana karyawan mempunyai komitmen kerja dengan instansi dan tanggung jawab karyawan terhadap perusahaan.

\section{METODE}

Riset menggunakan desain penelitian kepustakaan dan lapangan. Objek riset adalah pegawai Kantor Pusat Gereja Kristen Protestan Simalungun (GKPS) Pematangsiantar sebanyak 30 orang yang juga menjadi sampel penelitian. Jenis data yang digunakan adalah data kualitatif dan kuantitatif serta sumber data berasal dari data primer dan data sekunder. Data penelitian dikumpulkan dengan melaksanakan wawancara, dokumentasi, dan penyebaran kuesioner. Analisa data mencakup analisis data kualitatif dan analisis kuantitatif menggunakan analisis regresi.

\section{HASIL DAN PEMBAHASAN}

\section{Analisis Deskriptif Kualitatif}

Analisis deskriptif ialah metode untuk memperoleh gambaran dari cerita pekerjaan, koordinasi, serta kinerja pegawai pada Kantor Pusat Gereja Kristen Protestan Simalungun (GKPS) Pematangsiantar. Setelah pengujian data hingga tahap selanjutya adalah peneliti melakukan pengkajian analisis kualitatif sebagai gambaran fenomena dari variabel penelitian yang dibagi menjadi kategori interval sebagai berikut:

Tabel 1. Nilai Interval Kategori Jawaban Responden

\begin{tabular}{|c|c|}
\hline $\begin{array}{c}\text { Nilai } \\
\text { Interval }\end{array}$ & Kategori \\
\hline $1,00-1,80$ & Sangat Tidak Baik \\
\hline $1,81-2,60$ & Tidak Baik \\
\hline $2,61-3,40$ & Cukup Baik \\
\hline $3,41-4,20$ & Baik \\
\hline $4,21-5,00$ & Sangat Baik \\
\hline
\end{tabular}

Sumber: data diolah (2019)

\section{Gambaran Deskripsi Pekerjaan pada Kantor Pusat GKPS Pematangsiantar}

Dari total jawaban responden mengenai deskripsi pekerjaan terdapat hasil yang berada pada rata-rata 3,95 dengan kriteria jawaban baik. Kemudian nilai rata rata tertinggi sebesar 4,35 untuk dimensi fasilitas kerja pada indikator kesesuaian fasilitas kerja dengan kebutuhan pekerjaan. Sedangkan nilai rata-rata terendah sebesar 3,28 dengan kategori jawaban cukup baik berada pada dimensi kondisi pekerjaan dengan indikator kejelasan koordinasi dalam melaksanakan pekerjaan.

\section{Gambaran Koordinasi pada Kantor Pusat GKPS Pematangsiantar}

Secara keseluruhan koordinasi dengan dimensi komunikasi, kesadaran pentingnya koordinasi, kompetensi partisipan, kesepakatan, komitmen dan insentif koordinasi, serta kontinuitas perencanaan 
memiliki nilai rata-rata 3,73 dengan kriteria jawaban baik. Nilai rata-rata koordinasi tertinggi dengan nilai 4,21 dengan dimensi komunikasi pada indikator ketersediaan teknologi informasi yang memudahkan untuk berkomunikasi di dalam kantor. Nilai rata-rata terendah koordinasi dengan nilai 2,79 dengan kriteria jawaban cukup baik berada pada dimensi komunikasi dan indikator kejelasan informasi yang diberikan mengenai tugas-tugas yang akan dikerjakan.

\section{Gambaran Kinerja Pegawai pada Kantor Pusat GKPS Pematangsiantar}

Nilai rata- rata keseluruhan untuk kinerja ialah 3,81 dengan kriteria tanggapan baik dan nilai rata-rata paling tinggi dengan nilai 4, 42 dengan kriteria jawaban sangat baik berada pada dimensi komitmen kerja dengan indikaor kesediaan bekerja sepenuh hati. Nilai rata- rata terendah dengan nilai 2 , 79 dengan kriteria jawaban cukup baik terletak pada dimensi ketepatan waktu dengan indikator ketepatan waktu anda tiba di kantor.

\section{Analisis Deskriptif Kuantitatif Analisis Regresi Linear Berganda}

Riset ini mempunyai tujuan untuk mendapatkan dan menyelidiki pengaruh deskripsi pekerjaan dan koordinasi terhadap kinerja pegawai pada Kantor Pusat Gereja Kristen Protestan Simalungun (GKPS) Pematangsiantar. Analisis regresi linear berganda digunakan untuk mengetahui pengaruh variabel bebas $(\mathrm{X})$ dan variabel terikat (Y), yaitu X1 adalah deskripsi pekerjaan dan X2 merupakan koordinasi dan Y merupakan kinerja pegawai. Maka perhitungan menggunakan program SPSS untuk memperoleh nilai $a$ dan $b$ dengan notasi sebagai berikut:
Tabel 2. Hasil Regresi Linier Berganda

\begin{tabular}{|c|c|c|c|}
\hline \multirow[b]{2}{*}{ Model } & \multicolumn{2}{|c|}{$\begin{array}{c}\text { Unstandardized } \\
\text { Coefficients }\end{array}$} & \multirow{2}{*}{$\begin{array}{c}\begin{array}{c}\text { Standardized } \\
\text { Coefficients }\end{array} \\
\text { Beta }\end{array}$} \\
\hline & B & $\begin{array}{l}\text { Std. } \\
\text { Error }\end{array}$ & \\
\hline (Constant) & 13,766 & 7,974 & \\
\hline Deskripsi & ,546 & ,167 & ,427 \\
\hline Koordinasi &, 518 & ,167 & ,406 \\
\hline
\end{tabular}

a. Dependent Variable: Kinerja Pegawai

Sumber: data diolah (2019)

Melihat hasil pengolahan data pada Tabel 2 tersebut diperoleh model persamaan regresi linier berganda dengan $\hat{Y}=13,766+$ $0,546 \mathrm{X}_{1}+0,518 \mathrm{X}_{2}$, artinya terdapat pengaruh positif antara deskripsi pekerjaan dan koordinasi terhadap kinerja pegawai pada Kantor Pusat Gereja Kristen Protestan Simalungun (GKPS) Pematangsiantar.

\section{Koefisien Korelasi dan Koefisien Determinasi}

Perhitungan korelasi derajat atau kedalaman hubungan fungsional yang menjelaskan hubungan antar variabel, dinyatakan dengan koefisien korelasi yang sering disimbolkan dengan $r$, nilai $r_{\text {hitug }}$ dapat dilihat dari program SPSS sebagai berikut:

Tabel 3. Hasil Koefisien Korelasi dan Determinasi

\begin{tabular}{|c|c|c|r|r|}
\hline $\begin{array}{c}\text { Mod } \\
\text { el }\end{array}$ & $\mathbf{R}$ & $\begin{array}{c}\boldsymbol{R} \\
\text { Squar } \\
\boldsymbol{e}\end{array}$ & $\begin{array}{c}\text { Adjusted } \boldsymbol{R} \\
\text { Square }\end{array}$ & $\begin{array}{c}\text { Std. Error of } \\
\text { the Estimate }\end{array}$ \\
\hline 1 & $\mathbf{7 4 3}^{\mathrm{a}}$ &, $\mathbf{5 5 1}$ &, 529 & 4,823 \\
\hline
\end{tabular}

a. Predictors: (Constant), Deskripsi, Koordinasi

b. Dependent Variable: Kinerja Pegawai Sumber: data diolah (2019)

Berdasarkan nilai koefisien korelasi pada tabel tersebut, diperoleh korelasi nilai $r$ sebesar 0,743, artinya terdapat hubungan yang kuat dan positif antara variabel deskripsi pekerjaan dan koordinasi dengan kinerja pegawai pada Kantor Pusat Gereja Kristen Protestan Simalungun (GKPS) Pematangsiantar, kemudian diperoleh nilai 
koefisien determinasi $\mathrm{R}$ yaitu 0,551 artinya tinggi rendahnya kinerja pegawai sebesar $55,1 \%$ dapat dijelaskan oleh deskripsi pekerjaan dan koordinasi, sedangkan sisanya $44,9 \%$, dijelaskan oleh faktor lain seperti gaya kepemimpinan, motivasi, dan variabel lain yang tidak diteliti dalam penelitian ini.

\section{Pengujian Hipotesis \\ Uji Simultan (Uji F)}

Uji ini dilakukan lewat menguji signifikansi hubungan antara deskripsi dan koordinasi dengan kinerja pegawai secara simultan. Untuk melihat kebenarannya maka dilakukan uji hipotesis dengan menggunakan SPSS versi 21 yaitu dapat dilihat pada tabel di bawah ini:

Tabel 4. Perkiraan Nilai $\mathbf{F}_{\text {hitung }}$

\begin{tabular}{|c|r|r|c|c|c|}
\hline Model & $\begin{array}{c}\text { Sum of } \\
\text { Squares }\end{array}$ & df & $\begin{array}{c}\text { Mean } \\
\text { Square }\end{array}$ & F & Sig. \\
\hline Regressio & 1143,773 & 2 & 571,887 & $\mathbf{2 4 , 5 9 0}$ & $\mathbf{, 0 0 3}^{\mathbf{b}}$ \\
$n$ & & & & & \\
$\begin{array}{l}1 \\
\text { Residual } \\
\text { Total }\end{array}$ & 930,273 & 40 & 23,257 & & \\
& 2074,047 & 42 & & & \\
\hline
\end{tabular}

a. Dependent Variable: Kinerja Pegawai

b. Predictors: (Constant), Koordinasi, Deskripsi

Sumber: data diolah (2019)

Dari tabel di atas $F_{\text {hitung }}$ sebesar 24,590 > $\mathrm{F}_{\text {tabel }}$ pada tingkat 0,05 , (2 vs 43-2-1 ) adalah sebesar 3,23 atau dengan signifikansi $0,000<\alpha$ 0,05 maka $\mathrm{H}_{0}$ ditolak, artinya deskripsi pekerjaan dan koordinasi berpengaruh positif dan signifikan terhadap kinerja pegawai pada Kantor Pusat Gereja Kristen Protestan Simalungun

(GKPS)

Pematangsiantar.

\section{Uji Parsial (Uji t)}

Pengujian ini dilakukan secara parsial, yaitu untuk melihat diterima atau ditolaknya hipotesis. Jika $t_{\text {hitung }}>t_{\text {tabel }}$ atau signifikansi $\leq 0,05$ maka $\mathrm{H}_{0}$ ditolak. Untuk menguji kebenarannya maka dilakukan pengujian hipotesis dengan menggunakan program aplikasi SPSS versi 21.
Tabel 5. Perkiraan Nilai $t_{\text {hitung }}$

\begin{tabular}{|ll|r|r|}
\hline \multicolumn{1}{|c|}{ Model } & t & \multicolumn{1}{c|}{ Sig. } \\
\hline \multirow{2}{*}{ (Constant) } & 1,726 &, 092 \\
Deskripsi & $\mathbf{3 , 2 6 5}$ & $\mathbf{0 0 2}$ \\
& Koordinasi & $\mathbf{3 , 1 0 7}$ & $\mathbf{0 0 3}$ \\
\hline
\end{tabular}

a. Dependent Variable: Kinerja Pegawai

Sumber: data diolah (2019)

Dari tabel di atas didapat nilai thitung pada deskripsi pekerjaan $\left(\mathrm{X}_{1}\right)$ sebesar 3,265 $>\mathrm{t}_{\text {tabel }}$ dengan $\mathrm{df}=\mathrm{n}-\mathrm{k}-1 \quad(43-2-1=40)$ sebesar 2,021 atau taraf signifikansi 0,002 < a 0,05 maka $\mathrm{H}_{0}$ ditolak, artinya deskripsi pekerjaan berpengaruh positif dan signifikan terhadap kinerja pegawai pada Kantor Pusat Gereja Kristen Protestan Simalungun (GKPS) Pematangsiantar.

Kemudian nilai thitung pada koordinasi $\left(\mathrm{X}_{2}\right)$ sebesar 3,107 > dari tabel dengan $\mathrm{df}=\mathrm{n}$ $\mathrm{k}-1$, (43-2-1=40) sebesar 2,021 atau taraf signifikansi $0,003<0,05$ maka $\mathrm{H}_{0}$ ditolak, artinya koordinasi berpengaruh positif dan signifikan terhadap kinerja pegawai pada Kantor Pusat Gereja Kristen Protestan Simalungun (GKPS) Pematangsiantar.

\section{Evaluasi}

Deskripsi Pekerjaan Pada Kantor Pusat Gereja Kristen Protestan Simalungun (GKPS) Pematangsiantar

Deskripsi kerja merupakan hasil analisis mengenai kewajiban dan tanggung jawab dari sebuah pekerjaan. Deskripsi pekerjaan pada Kantor Pusat Gereja Kristen Protestan Simalungun

(GKPS) Pematangsiantar terdiri dari wewenang, tanggung jawab, kondisi pekerjaan, dan fasilitas kerja. Berdasarkan hasil penelitian yang diperoleh melalui kuesioner mendapat nilai rata-rata keseluruhan sebesar 3,95 dalam kriteria jawaban baik. Ada beberapa aspek yang dinilai baik namun masih berada di bawah nilai rata-rata keseluruhan, yaitu pada dimensi wewenang untuk indikator 
kesesuaian wewenang dengan posisi pekerjaan memperoleh rata-rata 3,93 dengan kriteria jawaban baik. Untuk meningkatkannya dengan cara menjelaskan kembali apa-apa saja yang menjadi hak dan kewajiban pegawai dalam menyelesaikan pekerjaannya. Pada dimensi tanggung jawab untuk indikator kejelasan tanggung dengan nilai rata-rata 3,42 dengan kriteria jawaban baik. Cara meningkatkannya, yaitu pimpinan Kantor Pusat Gereja Kristen Protestan Simalungun (GKPS) lebih memperjelas tanggung jawab untuk setiap unit bagian. Pada dimensi kondisi pekerjaan dengan indikator pemahaman peraturan pemerintah dengan rata-rata 3,86 dengan kriteria jawaban baik. Cara meningkatkannya, yaitu dengan cara mengingatkan kembali kepada pegawai mengenai peraturan pemerintah baik secara lisan dan tulisan yang berbentuk selebaran dan ditempel di dinding pengumuman dengan menggunakan bahasa yang mudah dimengerti oleh pegawai. Kemudian pada indikator kejelasan koordinasi dalam melaksanakan pekerjaan dengan rata-rata 3,28 dengan kriteria jawaban cukup baik. Cara meningkatkannya yaitu pimpinan memperbanyak melaksanakan koordinasi formal melalui rapat-rapat yang diadakan di kantor maupun koordinasi informal yang disampaikan setelah acara ibadah pagi agar pegawai memahami maksud dari koordinasi yang dilakukan.

\section{Koordinasi pada Kantor Pusat Gereja Kristen Protestan Simalungun (GKPS) Pematangsiantar}

Berdasarkan dimensi yang digunakan dan hasil penelitian yang diperoleh dapat dijelaskan bahwa koordinasi yang ada pada Kantor Pusat Gereja Kristen Protestan Simalungun (GKPS) Pematangsiantar sudah dalam kategori baik, yang terlihat dari komunikasi, kesadaran pentingnya koordinasi, kompetensi partisipan, kesepakatan, komitmen dan insentif koordinasi, serta kontinuitas perencanaan. Hal tersebut dapat dilihat dengan nilai ratarata keseluruhan dari koordinasi yang diperoleh sebesar 3,73 dengan kriteria jawaban baik. Namun masih ada beberapa aspek-aspek walaupun sudah dalam kategori baik tetapi masih rendah di bawah nilai ratarata keseluruhan yaitu, pada dimensi komunikasi dengan indikator kejelasan informasi yang diberikan mengenai tugastugas yang akan dikerjakan berada pada rata-rata 2,79 dengan kriteria jawaban cukup baik, cara meningkatkannya sebaiknya pimpinan memberikan informasi yang lebih lengkap dan terperinci dalam menyelesaikan suatu pekerjaan dengan cara menjelaskan dengan detail rincian pekerjaan tersebut seperti kapan pekerjaan tersebut selesai, kemana selanjutnya hasil pekerjaan tersebut diserahkan, berapa pegawai yang diperlukan untuk menyelesaikan pekerjaan tersebut agar tidak terjadi kesalahan komunikasi antara pimpinan dengan pegawai.

Pada dimensi kesadaran pentingnya koordinasi dengan indikator tingkat pengetahuan pelaksana terhadap koordinasi berada pada rata-rata 3,72 dengan kriteria jawaban baik, hal ini dapat ditingkatkan dengan cara pelaksana koordinasi lebih memerhatikan kesesuaian informasi yang disampaikan dengan pekerjaan pegawai. Pada indikator ketaatan terhadap hasil koordinasi dengan nilai rata-rata 2,84 dengan kriteria jawaban cukup baik, hal yang dilakukan untuk meningkatkannya yaitu dengan cara pimpinan harus menanamkan kepercayaan mengenai pentingnya kegiatan yang dikoordinasikan kepada pegawai sehingga pegawai akan lebih bersungguh-sungguh dalam melaksanakan kegiatan yang dikordinasikan. 
Pada dimensi kontinuitas perencanaan dengan indikator kejelasan informasi yang diterima berhubungan dengan pekerjaan berada pada rata-rata 3,70 dengan kriteria jawaban baik, untuk meningkatkannya dengan cara menyesuaikan informasi agar tidak bertentangan dengan apa yang telah dikerjakan pegawai. Pada indikator musyawarah terhadap perubahan hasil kesepakatan berada pada rata-rata 3,70 dengan kriteria jawaban baik hal ini dapat ditingkatkan dengan cara meningkatkan hasil musyawarah yang dilakukan oleh pegawai Kantor Pusat Gereja Kristen Protestan Simalungun (GKPS) Pematangsiantar yang apabila sewaktuwaktu mendapat kendala dalam melaksanakan koordinasi.

\section{Kinerja Pegawai pada Kantor Pusat Gereja Kristen Protestan Simalungun (GKPS) Pematangsiantar}

Kinerja merupakan perolehan yang didapat dari pekerjaan yang telah diselesaikan oleh pegawai. Kinerja dapat berupa hasil yang baik maupun hasil yang buruk. Kendati demikian hasil tersebut adalah prestasi kerja yang diukur melalui kuantitas, kualitas, ketepatan waktu, efektivitas, kemandirian, dan komitmen kerja. Melalui pembuktian data dengan nilai rata-rata keseluruhan sebesar 3,81 dengan kriteria jawaban baik maka kinerja pegawai pada Kantor Pusat Gereja Kristen Protestan Simalungun (GKPS) Pematangsiantar dapat dinilai baik. Namun masih ada beberapa aspek walaupun dalam kategori yang baik tetap masih berada di bawah nilai rata-rata keseluruhan.

Pada dimensi ketepatan waktu untuk indikator tidak menunda-nunda waktu dalam bekerja dengan nilai rata-rata 3,77 dengan kriteria jawaban baik dan hal yang dilakukan unntuk meningkatkannya yaitu dengan cara pegawai untuk mengingat durasi dalam menuntaskan pekerjaannya. Pada indikator hadir tepat waktu dengan nilai rata-rata 2,79 dengan kriteria jawaban cukup baik, untuk meningkatkannya perlu pembinaan yang dilakukan oleh pimpinan terhadap pegawai yang sering datang terlambat dengan cara melaksanakan penerapan pemberian penghargaan bagi pegawai yang memiliki ketepatan hadir yang baik dan sanksi bagi pegawai yang tidak mengikuti aturan jam kerja agar pegawai lebih bersemangat dalam bekerja dan lebih menaati peraturan yang sudah ditetapkan sebelumnya guna mencapai tujuan bersama yang lebih baik. Pada dimensi efektivitas dengan pada indikator mengerjakan pekerjaan dengan benar didapat angka rata- rata 2, 81 dengan kriteria tanggapan cukup baik, perihal ini bisa dioptimalkan dengan cara pimpinan memberikan motivasi serta pelatihan pada pegawai yang selalu menyelesaikan pekerjaannya dengan mutu yang kurang baik supaya tugas berikutnya bisa dituntaskan tepat durasi dan benar. Pada indikator berinovasi dalam melakukan pekerjaan dengan angka rata- rata 3, 58 dan kriteria jawaban bagus, dalam perihal ini hendaknya pimpinan lebih membebaskan pegawai dalam mengemukakan pendapat ataupun ide yang dimilikinya yang bertujuan untuk meningkatkan kinerjanya. Pada dimensi kemandirian dengan indikator siap menghadapi tantangan dengan nilai ratarata 3, 77 dengan kriteria jawaban baik, perihal yang perlu dilakukan yaitu dengan kiat pimpinan memberikan dukungan sehingga pegawai yang menyukai tantangan lebih mengarah ke hal yang lebih positif. 


\section{SIMPULAN DAN SARAN}

\section{Simpulan}

Analisis deskriptif kualitatif tentang deskripsi pekerjaan diperoleh nilai rata-rata tertinggi berada pada dimensi fasilitas kerja untuk indikator kesesuaian fasilitas dengan kebutuhan pekerjaan. Sedangkan nilai ratarata terendah dengan kriteria jawaban cukup baik berada pada dimensi kondisi pekerjaan untuk indikator kejelasan koordinasi dalam melaksanakan pekerjaan. Lalu untuk hasil analisis deskriptif kualitatif tentang koordinasi diperoleh nilai nilai rata-rata tertinggi untuk dimensi komunikasi dengan indikator ketersediaan teknologi informasi yang memudahkan untuk berkomunikasi. Sedangkan nilai rata-rata terendah berada pada dimensi komunikasi dengan indikator kejelasan informasi yang diberikan mengenai tugas-tugas yang akan dikerjakan.

Selanjutnya hasil analisis deskriptif kualitatif tentang kinerja pegawai diperoleh nilai rata-rata tertinggi berada pada dimensi komitmen kerja untuk indikator bekerja sepenuh hati. Sedangkan nilai rata-rata terendah berada pada dimensi ketepatan waktu untuk indikator hadir tepat waktu. Hasil analisis regresi linier berganda menunjukkan terdapat pengaruh positif antara deskripsi pekerjaan dan koordinasi terhadap kinerja pegawai pada Kantor Pusat Gereja Kristen Protestan Simalungun (GKPS) Pematangsiantar.

Analisis koefisien korelasi menunjukkan yang artinya terdapat hubungan yang kuat dan positif antara deskripsi pekerjaan dan koordinasi dengan kinerja pegawai pada Kantor Pusat Gereja Kristen Protestan Simalungun (GKPS) Pematangsiantar. Kemudian tinggi rendahnya kinerja pegawai dapat dijelaskan oleh deskripsi pekerjaan dan koordinasi. Hasil pengujian hipotesis secara simultan dengan uji $\mathrm{F}$ menunjukkan deskripsi pekerjaan dan koordinasi berpengaruh positif dan signifikan terhadap kinerja pegawai pada Kantor Pusat Gereja Kristen Protestan Simalungun (GKPS) Pematangsiantar. Hasil pengujian hipotesis secara parsial dengan uji $\mathrm{t}$ menunjukkan deskripsi pekerjaan dan koordinasi berpengaruh positif dan signifikan terhadap kinerja pegawai pada Kantor Pusat Gereja Kristen Protestan Simalungun (GKPS) Pematangsiantar secara parsial.

\section{Saran}

Memaksimalkan deskripsi pekerjaan pada Kantor Pusat Gereja Kristen Protestan Simalungun (GKPS) Pematangsiantar sebaiknya pimpinan memperbanyak melaksanakan koordinasi formal melalui rapat-rapat yang diadakan di kantor maupun koordinasi informal yang disampaikan setelah acara ibadah pagi agar pegawai memahami maksud dari koordinasi yang dilakukan. Untuk memaksimalkan koordinasi pada Kantor Pusat Gereja Kristen Protestan Simalungun

(GKPS) Pematangsiantar, sebaiknya pimpinan memberikan informasi yang lebih lengkap dalam menyelesaikan suatu pekerjaan dengan cara menjelaskan dengan detail rincian pekerjaan tersebut seperti kapan pekerjaan tersebut selesai, kemana selanjutnya hasil pekerjaan tersebut diserahkan, berapa pegawai yang diperlukan untuk menyelesaikan pekerjaan tersebut agar tidak terjadi kesalahan komunikasi antara pimpinan dengan pegawai.

Memaksimalkan kinerja pegawai pada Kantor Pusat Gereja Kristen Protestan Simalungun (GKPS) Pematangsiantar sebaiknya pimpinan memperhatikan ketepatan waktu dan membina pegawai yang sering datang terlambat dan tidak mengikuti ibadah pagi dengan cara 
melaksanakan penerapan pemberian penghargaan bagi pegawai yang memiliki kinerja yang baik dan sanksi bagi pegawai yang tidak mengikuti aturan jam kerja agar pegawai lebih bersemangat dalam bekerja dan lebih menaati peraturan yang sudah ditetapkan sebelumnya guna mencapai tujuan bersama yang lebih baik.

Sehubungan dengan keterbatasanketerbatasan yang ada pada penulis, penelitian ini masih terdapat kelemahankelemahan dan belum dapat mengungkap seluruh variabel yang dapat mempengaruhi kinerja pegawai sebagai bahan masukan untuk penelitian selanjutnya, perlu memperbanyak variabel penelitian yang tidak dijelaskan dalam penelitian ini seperti disiplin, pelatihan, kepemimpinan, kompensasi, motivasi, dan lain-lain.

\section{DAFTAR PUSTAKA}

Gaol, Jimmy L. 2014. Human Capital. Jakarta: PT Gramedia

Handayaningrat, Soewarno. 2000.

Pengantar Studi Ilmu Administrasi dan Manajemen. Jakarta: Haji Masagung.

Handoko, T. Hani 2003. Manajemen. Edisi

2. Yogyakarta: BPFE

Moekizat. 2008. Koordinasi. Bandung: Mandar Maju
Mangkunegara, Anwar Prabu. 2017. Manajemen Sumber Daya Manusia Perusahaan. Bandung: PT. Remaja Rosdakarya.

Octorano, D. F. (2015). Pengaruh Koordinasi, Kompetensi Dan Disiplin Terhadap Kinerja Pegawai Unit Layanan Pengadaan Kementerian Agama Pusat (Ulp Kemenag Pusat). MIX: Jurnal Ilmiah Manajemen, 5(1).

Pattisahusiwa, Salmah. 2013. Pengaruh Job Description dan Job Specification terhadap Kinerja Proses. Samarinda: Jurnal Akuntabel. Jurnal. Volume: 10, No: 1 (Maret 2013).

journal.feb.unmul.ac.id/index.php/aku ntabel/article/download/53/50.

Diakses 2019.

Rivai, Veithzal. 2015. Manajemen Sumber Daya Manusia untuk Perusahaan. Jakarta: Raja Grafindo Persada.

Robbins, Stephen P. 2006. Perilaku Organisasi. Edisi Kesepuluh. Indonesia: PT. Macan Jaya Cemerlang.

Syelviani, M. (2017). Pengaruh Deskripsi Pekerjaan terhadap Kinerja Pegawai Negeri Sipil pada Kantor Camat Tembilahan. Journal of Economic, Bussines and Accounting (COSTING), 1(1), $43-55$. https://doi.org/10.31539/costing.v1i1.48 